\title{
The resilience and its relation to the people who acquired physical deficiency socio demographic economical profile \\ ORIGINAL
}

Janaíne Chiara Oliveira Moraes ${ }^{1}$, Inácia Sátiro Xavier de França², Francisco Stélio de Sousa ${ }^{3}$, Gicely Regina Sobral da Silva Monteiro ${ }^{4}$, Regina Célia de Oliveira ${ }^{5}$, Rayrla Cristina de Abreu Temoteo ${ }^{6}$, Danielle Chianca de Andrade Moraes ${ }^{7}$, Ana Clarissa Luna Gomes ${ }^{8}$

\section{Abstract}

Objective: to investigate the association between the socio demographic and economical factors to the resilience of people who acquired physical deficiency.

Methodology: it is about a descriptive and exploratory design with the quantitative approach, developed in the Foundation Center for Integrated Support for patients with Disabilities in João Pessoa/PB, with 69 physical deficient people.

Results: The found resilience average among the population was of 138.26. In the socio demographic and economical characteristics considered, only the gender and schooling showed statistical inferences on the participants' resilience, where the condition to being men and have a satisfactory schooling level favored the adaptive capacity development.

Conclusion: in this study, in despite of the low income profile and poor education, the individuals showed high resilience scores when compared to other populations. It is believed that the resilience does not depend on some factors, taking us to think this construct as a trait that can be constructed by any individual.
1 Nurse. Nursing Master in the Graduation Nursing Associated Program; Pernambuco University/ Paraíba State University; Professor at the Campina Grande Federal University; Nursing Department; Cajazeiras, PB, Brazil.

2 Nurse. Nursing PhD; Ceará Federal University; Professor at Paraíba State University (UEPB). Nursing Department. Campina Grande, PB, Brazil.

3 Nurse. Nursing PhD; Ceará Federal University; Professor at Paraíba State University (UEPB). Nursing Department. Campina Grande, PB, Brazil.

4 Nurse. Nursing Master in the Graduation Nursing Associated Program; Pernambuco University/ Paraíba State University. Recife, PE, Brazil.

5 Nurse. Nursing PhD; Ribeirão Preto Nursing School. Professor at Pernambuco University. Nursing Department. Recife, PE, Brazil.

6 Nurse. Public Health Master; Paraíba State University (UEPB). Professor at the Campina Grande Federal University. Nursing Department. Cajazeiras, PB, Brazil.

7 Nurse. Nursing Master in the Graduation Nursing Associated Program; Pernambuco University / Paraíba State University. Pernambuco Public Health Service Basic Care.Garanhus Health Secretary. Recife, PE, Brazil. 8. Nurse. Pernambuco University Multiprofessional Residence in Public Health; Non-transmittable disease Health Promotion and Coordination. Jaboatão dos Guararapes Health Secretary. Recife, PE, Brazil.

\section{Contact information:}

\section{Janaíne Chiara Oliveira Moraes}

झ janainechiara@hotmail.com 


\section{Introduction}

The deficiency has been setting up in Brazil as a relevant question to many social actors, health professionals and managers, especially during the last years, due to its implications in the society scope as an everything. The 2010's census points out that in the country there are $23.9 \%$ people who present any kind of deficiency, what corresponds to 45.6 millions of Brazilian. When it is about the predominance per nature, the physical deficiency is presented as the second most quantitative of cases, affecting $7 \%$ of the population, losing only for the visual deficiency which affects to $18.6 \%$ of the people ${ }^{[1]}$.

However, in despite of the general expressed panorama, concrete data relevant to the deficiency rate specifically per origin and causes are not available. A study conducted in 2006 by the Brazilian Database Federation (FEBRABAN) emphasizes that, from the total, $56.6 \%$ of the deficiencies are acquired for the most variable causes, being that, regarding the physical deficiency, more than $77 \%$ of the cases are contracted after the birth ${ }^{[2]}$.

In this context, it is important to emphasize that beyond the motor restrictions, there are a lot of changes happening with the person who becomes deficient that comes from bladder and sexual dysfunctions to psychological changes, at the body image and at the interaction with the environment ${ }^{[3]}$. Furthermore, the transformations caused in the senses, in the behavior and the body structures, can interfere at the performance of rules and roles, at the affective capacity and at the work performance, reflecting in the identity formation and mainly at the affect people's coping strategies ${ }^{[4]}$.

In this perspective is inserted the resilience concept, understood by some authors as the human capacity to get strong and changed from many situations without having the mental health necessarily affected. More them reorganize themselves in front of the stressor and adapt to the extern reality, the resilient being must be restructured in a healthy way to them and to their relations with the environment that they live ${ }^{[5-6]}$. Thus, the person who acquires a physical deficiency and can develop high resilience level, feel the difficulties posed by their deficiency, however live them in a softer way, presenting resources to overcome them ${ }^{[4]}$.

Some authors added that the multiple factors contribute to adaptative answers in front of the deficiency and those, depend of how did the acquisition occurred, the vital cicle stage and the previous personal story, the kind and the deficiency seriously, the gender, the income, the educational level, the psychodynamic operation, the cultural aspect, the self-stem, the familiar and social support and the financial resources existhance that facilitate or hinder the assistive technologies obtaining, medicines and treatments ${ }^{[7-8]}$.

Given this approach this research development is justified, as the acquired physical incapacities rise indicates the urgent necessity of researches that show the affection pattern in each culture, as the susceptible population socio-demographic and economical profile, to subsidize the reasonable preventive measures elaboration that can transform the morbidity rate in the most incident regions, decreasing the costs on health and the generated impacts.

This becomes more valorous by the relevance in studying the factors that promote the resilience in people who acquired physical deficiency, because, considering the resilience as a construct that can be stimulated, the knowledge of characteristic that lead to it, provide subsidy to the health professional intervention, from them, including the nurse, in a way to make concrete a more effective assistance, with an approach turned to the prevention actions, promotion and individuals recovery with physical sequels, where the coping capacity is emphasized and the individual incapacities aren't the only caring focus. Given the above, this work aimed to investigate the association between the socio demographic and economical factors with the people who acquired physical deficiency resilience. 


\section{Method}

It is a descriptive, exploratory and cross-sectional study, with quantitative approach, conducted with data coming from the researched names "People who acquired physical deficiency resilience: life quality implications", developed by the Foundation Integrated Support Centre for Disabled People Foundation (FUNAD), located in João Pessoa/ Paraíba.

The sample was constituted by 69 people with deficiency, who were recruited according to the inclusion criteria: be 18 years old or older; present physical deficient acquired in at least one year; be present at the place of study during the collect moment an consent, free and clarified to answer the established protocols. Were excluded the other kinds of deficiency that were not the physical; the congenital physical deficiency and the individuals who show an incapacity to communicate orally and or/ cognitive deficit, evaluated by the mental state mini exam, in the Portuguese version[9].

Data were obtained from May to June 2015, being the target population addressed in the waiting room at the Physical Deficiency People Attendance Coordination (CODAFI), from Monday to Friday, during the operation service shifts, observing previously the stagger. To the collection was used a socio demographic quest, elaborated specifically to the studied population and the Resilience Scale created originally by Wagnild and Young in 1993 and validated to Portuguese by the Pesce study in 2005. This scale is constituted for 25 items with the answer at the Likert format, distributing in the factors: "Actions and Values resolution", "Independence and Determination" and 'Self-confidence and the capacity of adaptation to situations". Its marks shall vary between 25 to 175 points, with value indicating high resilience ${ }^{[10]}$

The individuals able to be included in the study were invited to participate and, those who accepted voluntarily, were at the same time guided about the aspects evolving the research and about the Term of Consent signature. The instruments were available in a individual way and in reserved place, were the duration average was 20 minutes.

To data analyze was considered as a dependent variable the resilience and as the independent variable that includes the individual's socio demographic and economical characteristics: gender, age, marital status, schooling, religious activity practices, employment, individual and familiar income. The information were inserted in a databases made on the Statistical Package for Social Sciences (SPSS), version 21.0, being the analyzes made on the same program, using the central tendency measures (average), dispersion (standard deviation), frequency distribution and test application as T of Student, Leyene equal variance, Pearson correlations and ANOVA to associations between the variables, accepting as statically significant a $p \leq 0.05$. The calculated results were grouped and exposed in crossed tables and discussed in the light of the pertinent literature.

This work development respected all the ethical and legal aspects of the Research with human beings, included at the new Resolution no 466 from December 12, 2012, being submitted and approved by the Paraíba State University (UEPB) Research Ethic Committee, under CAAE no 42635115.2.0000.5187.

\section{Results}

The study included 69 people with acquired physical disability. The sample average was 39.52 years old (SD=11.19), varying between 19 (minimum) and 71 (maximum), with a median of 40 , being predominately constituted by male individuals (63.8\%, $\mathrm{n}=44$ ), who declared to be married or to live in a stable union with a partner $(52.2 \%, \mathrm{n}=36)$.

Regarding to schooling, $39.1 \%(n=27)$ of the participants had the primary school incomplete and only $7.2 \%(n=5)$ had concluded the college. However, if analyzed in a summarized way, the data points out that, only $12 \%$ of the individuals ( 5 individuals who completed the college, added to the 3 individuals who hadn't completed the college) had a schooling 
time higher than 12 years. For the religious activities practices, $71.0 \%(n=49)$ said to attend a kind of religion.

The most part hadn't any work activity at the collection moment (82.6\%, $n=57)$, situation justified by $45.6 \% \quad(n=26)$ to be due to the physical limitations disrupting the return to the functions practices previously. In average, those people are out of the market for 5.47 years $(S D=6.35)$,_median of 5, maximum time 26 and minimum time 1 year. Among the employed individuals, equivalent to $17.4 \%(n=12)$, only $8.3 \%(n=1)$ was gazette or had a formal employee.

At the evaluation of the data according to income, it is noticed that $79.7 \%(n=55)$ of the deficient people depends on the State resource to their survival, being that from those, $50.9 \%(n=28)$ of the cases is about Continued Installment Benefit (BPC). The individual income kept about a minimum wage, averaging 2.87 (SD=0.89), median 2.0, minimum 1 and maximum 6 . The familiar income varied from 2 to 3 minimum wages $(49.3 \%, n=34)$ averaging 2.65 ( $\mathrm{SD}=1.93)$, median 2.0, minimum 1 and maximum 10. It is important to emphasize that $20.4 \% \quad(n=21)$ of the family survive with only one minimum wage, possible coming from the deficient person income.

Regarding the found resilience level, verified through the Resilience Scale application, the average was 138.26 ( $S D=16.14)$, median 140, minimum 93 and maximum 175. The average for the factor "Action and Values resolution" was 81.10 (SD=81.10), to "Independence and Determination" 29.36 (SD= 5.33) and to "Self-stem and capacity to adapt to situations", 27.79 (SD-4.09). It is noteworthy that those measurers can't be compared among them, because have different measures.

From the association with the socio demographic profile, the table 1 exposes the correlation conducted with the gender variable. It can be observed that the gender had a significant relation $(p=0.05)$ with the general resilience, where the men presented high averages. Despite of not being significant, the others resilience factors measure were most elevated at the male population.

Table 2 present the compilations between resilience and the participants' marital status. To that, was regrouped the single individuals, separated and divorced at the category "single" and the married or who lived with a partner in a stable union at the category "married". It was noticed that, generally, this variable has not demonstrated a significant relation to the resilience. However, when compared to the married, the single present a bigger average at the factors: "Value and Actions Resolution", "Self-stem and capacity to adapt to situations" and general resilience.

Table 1. Relation between the Resilience average scores of people who acquired physical deficiency according to the variable gender. João Pessoa, PB, 2015.

\begin{tabular}{|c|c|c|c|c|c|c|}
\hline & \multirow{2}{*}{ Gender } & \multirow{2}{*}{ Ave. } & \multirow{2}{*}{ SD* } & \multirow{2}{*}{$\mathbf{P}$} & \multicolumn{2}{|c|}{$\mathrm{Cl} * * 95 \%$} \\
\hline & & & & & Inf. & Sup. \\
\hline Actions and values Resolution & $\begin{array}{l}\text { Fem. } \\
\text { Mal. }\end{array}$ & $\begin{array}{l}78.64 \\
82.50\end{array}$ & $\begin{array}{l}10.57 \\
8.91\end{array}$ & 0.11 & -8.63 & 0.91 \\
\hline $\begin{array}{l}\text { Independence and } \\
\text { determination }\end{array}$ & $\begin{array}{l}\text { Fem. } \\
\text { Mal. }\end{array}$ & $\begin{array}{l}27.76 \\
30.27\end{array}$ & $\begin{array}{l}6.39 \\
4.45\end{array}$ & 0.06 & -5.12 & 0.10 \\
\hline $\begin{array}{l}\text { Self-stem and capacity to } \\
\text { adapt to situations }\end{array}$ & $\begin{array}{l}\text { Fem. } \\
\text { Mal. }\end{array}$ & $\begin{array}{l}26.92 \\
28.29\end{array}$ & $\begin{array}{l}4.41 \\
3.86\end{array}$ & 0.18 & -3.41 & 0.66 \\
\hline General Resilience & $\begin{array}{l}\text { Fem. } \\
\text { Mal. }\end{array}$ & $\begin{array}{l}133.32 \\
141.06\end{array}$ & $\begin{array}{l}18.75 \\
13.90\end{array}$ & 0.05 & -15.65 & 0.01 \\
\hline
\end{tabular}

Note: *SD - Standard Deviation;** $\mathrm{Cl}$ - confidence interval.

Source: Empirical research data, 2015. 
Table 2. Relation between the Resilience average scores of people who acquired physical deficiency according to the variable Marital Status. João Pessoa, PB, 2015.

\begin{tabular}{|c|c|c|c|c|c|c|}
\hline & \multirow{2}{*}{$\begin{array}{l}\text { Marital } \\
\text { status }\end{array}$} & \multirow{2}{*}{ Ave. } & \multirow{2}{*}{ SD** } & \multirow{2}{*}{$\mathbf{P}$} & \multicolumn{2}{|c|}{$\mathrm{Cl} * * * 95 \%$} \\
\hline & & & & & Inf. & Sup. \\
\hline $\begin{array}{l}\text { Actions and values } \\
\text { Resolution }\end{array}$ & $\begin{array}{c}\text { Single } \\
\text { Married } \\
\text { Widower }\end{array}$ & $\begin{array}{c}82.34 \\
80.22 \\
73\end{array}$ & $\begin{array}{c}9.17 \\
10.12 \\
*\end{array}$ & 0.37 & -2.57 & 6.82 \\
\hline $\begin{array}{l}\text { Independence and } \\
\text { determination }\end{array}$ & $\begin{array}{c}\text { Single } \\
\text { Married } \\
\text { Widower }\end{array}$ & $\begin{array}{c}29.50 \\
29.47 \\
21\end{array}$ & $\begin{array}{l}5.27 \\
5.34 \\
*\end{array}$ & 0.98 & -2.54 & 2.60 \\
\hline $\begin{array}{l}\text { Self-stem and capacity to } \\
\text { adapt to situations }\end{array}$ & $\begin{array}{c}\text { Single } \\
\text { Married } \\
\text { Widower }\end{array}$ & $\begin{array}{c}28.62 \\
27.13 \\
25\end{array}$ & $\begin{array}{l}4.55 \\
3.59 \\
\star\end{array}$ & 0.13 & -0.49 & 3.46 \\
\hline General resilience & $\begin{array}{c}\text { Single } \\
\text { Married } \\
\text { Widower }\end{array}$ & $\begin{array}{c}140.46 \\
136.83 \\
119\end{array}$ & $\begin{array}{c}15.97 \\
16.21 \\
*\end{array}$ & 0.36 & -4.17 & 11.44 \\
\hline
\end{tabular}

Note: *There was only one widow participant, because of it was not possible to estimate a standard deviation and the inferential calculation;**SD - Standard Deviation;*** Cl - Confidence interval.

Source: Empirical research data, 2015.

Regarding to religion, there was no statistical interference on the dependent variable, although the individuals that affirmed to be inserted in spiritual practices had shown a few lower resilience average in the factors: "Actions and Value Resolution", "Independence and determination" and general resilience (Table 3).

Table 4 highlights the comparisons between resilience and the variable work, which was divided in the employed group equivalent to the alternative "Yes" and unemployed to the assertive "no". This relation hadn't statistical significant differences with the resilience. Although, the individuals who referred to be practicing a work activity had higher averages in the questions "Independence and determination" and general resilience.

Table 3. Relation between the Resilience average scores of people who acquired physical deficiency according to the variable religious activities practical. João Pessoa, PB, 2015.

\begin{tabular}{|c|c|c|c|c|c|c|}
\hline & \multirow{2}{*}{$\begin{array}{l}\text { Religious } \\
\text { activity }\end{array}$} & \multirow{2}{*}{ Ave. } & \multirow{2}{*}{ SD* } & \multirow{2}{*}{$\mathbf{P}$} & \multicolumn{2}{|c|}{$\mathrm{Cl} *$ * 95\% } \\
\hline & & & & & Inf. & Sup. \\
\hline $\begin{array}{l}\text { Actions and values } \\
\text { Resolution }\end{array}$ & $\begin{array}{l}\text { Yes } \\
\text { No }\end{array}$ & $\begin{array}{l}80.97 \\
81.40\end{array}$ & $\begin{array}{l}10.51 \\
7.37\end{array}$ & 0.87 & -5.57 & 4.72 \\
\hline $\begin{array}{l}\text { Independence and } \\
\text { determination }\end{array}$ & $\begin{array}{l}\text { Yes } \\
\text { No }\end{array}$ & $\begin{array}{l}28.87 \\
30.55\end{array}$ & $\begin{array}{l}4.85 \\
6.32\end{array}$ & 0.24 & -4.48 & 1.14 \\
\hline $\begin{array}{l}\text { Self-stem and capacity to } \\
\text { adapt to situations }\end{array}$ & $\begin{array}{l}\text { Yes } \\
\text { No }\end{array}$ & $\begin{array}{l}27.79 \\
27.80\end{array}$ & $\begin{array}{l}4.40 \\
3.33\end{array}$ & 0.99 & -2.18 & 2.18 \\
\hline General resilience & $\begin{array}{l}\text { Yes } \\
\text { No }\end{array}$ & $\begin{array}{l}137.65 \\
139.75\end{array}$ & $\begin{array}{l}17.24 \\
13.32\end{array}$ & 0.62 & -10.69 & 6.50 \\
\hline
\end{tabular}

Note: ${ }^{*} \mathrm{SD}-$ Standard Deviation; ${ }^{*} \mathrm{Cl}$ - Confidence interval.

Source: Empirical research data, 2015. 
Table 4. Relation between the Resilience average scores of people who acquired physical deficiency according to the variable work. João Pessoa, PB, 2015.

\begin{tabular}{|l|c|c|c|c|}
\hline & Employed & Ave. & SD* & P \\
\hline \multirow{2}{*}{ Actions and values Resolution } & Yes & 80.41 & 9.95 & 0.78 \\
\hline \multirow{2}{*}{ Independence and determination } & No & 81.24 & 9.67 & 0.53 \\
\hline \multirow{2}{*}{ Self-stem and capacity to adapt to situations } & Yes & 30.25 & 4.15 & 5.56 \\
\hline \multirow{2}{*}{ General resilience } & No & 29.17 & 4.01 & 0.73 \\
\cline { 2 - 5 } & Yes & 28.16 & 4.14 & 0.89 \\
\hline
\end{tabular}

Note:*SD - Standard Deviation.

Source: Empirical research data, 2015.

Lastly, the table $\mathbf{5}$ shows the crossing to the numeral variables. From those, the schooling was the only one to present a $p$ statistically significant $(<0.05)$ with the participants' resilience, relating in a positive way to the factor "Self-stem and capacity to adapt to situations".

\section{Discussion}

\section{Participants' Socio demographic and economical profile}

The initial finding about the age defines the population as belonging to the adult aging. A similar profile was observed in a study developed with the 43 physical deficient people frequenting rehab centers in Londrina/ Paraná, where the average was 39.9 years old $( \pm 13,4) 11$ This situation rise to a critical problematic, where the big portion of the adults physical deficient people in the country competes to the lost of productive manpower, to higher spending in health and security, in addition to demand from the society a reorganization to support and capacity professionally those public, aiming to create ways to facilitate a healthy life with a high independence and autonomy level[12].

Furthermore, the male deficiency predominance in this sample coincides with other researches data

Table 5. Relation between the Resilience average scores of people who acquired physical deficiency according to the numerical variables: age, individual income, familiar income and schooling. João Pessoa, PB, 2015

\begin{tabular}{|l|c|c|c|c|}
\hline & Age & $\begin{array}{c}\text { Individual } \\
\text { income }\end{array}$ & $\begin{array}{c}\text { Familiar } \\
\text { income }\end{array}$ & Schooling \\
\hline Actions and values Resolution & 0.01 & 0.16 & -0.05 \\
\hline Independence and determination & 0.02 & 0.16 & 0.15 & -0.03 \\
\hline Self-stem and capacity to adapt to situations & -0.07 & 0.15 & 0.03 & $\mathbf{0 . 2 4 *}$ \\
\hline General resilience & -0.01 & 0.19 & 0.03 & 0.15
\end{tabular}

Note: ${ }^{*} p<0,01 ;{ }^{*} p<0,05$

Source: Empirical research data, 2015. 
with a similar approach[13-15]. This gender prevalence can be easily shimmered in reason to the own male characteristics, in which the social cultural and work practices are more risked and condition the men to an elevated risk of traumas, specially the linked to traffic and work accidents, increasing the rate of acquisition of disabling physical sequels when compared to women ${ }^{[16]}$.

Epidemiological investigations that evaluated the most variable accident occurrence, such as query conducted at the fire department in Goiânia, evolving 1176 occurrences with motorcycles in 2008, shows the predominance of male in $73 \%$ of the cases $^{[17]}$. Santana et al. ${ }^{[18]}$ share the same emergency mobile service (SAMU) in a city from Minas Gerais, where the case proportion occurred to four men to each attacked woman.

Regarding the marital status, the most part of the researched people said to live in a stable union with a partner, a fact that present as a favorable factor in the participants' profile. Authors consider that the consummation of a solid and lasting relationship, beyond allowing the familiar structure, provides a certain affective stability to the physical deficient people ${ }^{[12]}$. However, it is added that are constants the sexual difficulties mentioned for those individuals and that disrupt the search for a partner.

An interview developed with the people passing through acquired physical necessities in Iguatu/ Ceará evidenced changes in positions performance interfering at the sexual pleasure; absence of sensibility at the genital organs and libido decrease with a consequent reduction on the sexual acting number and partners availability ${ }^{[19]}$. In addition to this come the myths rooted in prejudicial ideas that implanted the conception that the physical deficient people are lacking of feeling and sexual needs, or from the opposite, have uncontrolled and exacerbated desires; are less attractive, undesirable and unable to keep a loving relationship; have sexual dysfunctions regarding the desire, to excitement and to the orgasm. Those beliefs turns to a obstacle to their affective life, to a home solidification, empower the discrimination and above all, commit the health care while the abuse situations are neglected and the right to access the sexual education and preventions sexually transmittable are hidden ${ }^{[20]}$.

Regarding the schooling, it is visible the participants' low instruction level. According to a research about the young and adults with especial necessities educations, it is shown that the physical deficient people was the one who less enrolled in schools during the considered period to the research ${ }^{[21]}$. Such conditions propagates an excluding educational situation of the deficient people in Brazil, and that, in despite of the immoderate efforts, the number of students in primary school and superior is still incipient. Among the main cited difficulties as obstacle at the educational process are: the school and families resistance to enroll the physical deficient people at the teaching institutions; the transports with caring technology increasing absence and specialized prepare to teachers; the little scholar adapted transport covering; the lack of effective pedagogical strategies and the own architectural limitations, that even at the universities, sets up barrers to the teaching-learning process ${ }^{[22-23]}$.

In the studied population, the activities practices linked to religion became common to the majority. The religiosity presents a form to cope the adverse events set up as diseases or traumas that cause threaten to life. The knowledge about the spiritual profile of patients who live under a bigger vulnerability facilitates to the health professionals the suitable intervention elaboration of to each individual[24].

The found results, in which a great part of the participants are unemployed, denounces a reality realized long time ago referring to the physical deficient people economical aspects. A research conducted in 2014 at the population census, shows that in 2010 the physical deficient people population with any occupation were only $23.6 \%$ of the workers and that more than the half of the 44 millions physical deficient people with an economical 
active aging were unemployed, a value that counts $31.3 \%$ of the total of unemployed people in the country in this period ${ }^{[22]}$.

The students of this theme see this panorama as a consequence of the social segregation and physical space restriction that ends to distance people with some deficiency to an spread living relations, those including to the work activities, frustrating them from the others common experiences. It is added to the problematic, factors as the professional disqualification, the citizen right unknowing, the society prejudice, the own relation to the deficiency, to the public and mainly to the family, and also the work spaces inadequate structure that contributes with no doubt to the significant part of this group at the unemployment index ${ }^{[25]}$.

Another relevant point about this question is at the non-search for work after the deficiency diagnosis, even that in some situations would be possible the insertion in adapted jobs. What is implicit in the reports is the fear for losing the benefits given by the State, what takes the individual to get even farer from the formal job, much time for self-indulgence. This characteristic was noticed at the discourse of many interviewed and ends powering the physical deficient people marginalization and poverty.

The financial support available by the government has a notable importance to decrease the faced economical difficulties, above all when the individual is suddenly affected by a circumstance that leads him to leave his subsidy activities. However, this can't be the guidance logic [26]. The lack of employability to the physical deficient people impacts financially the family, overloading the social providence, and has deleterious consequences to the economy in the country. The professional qualification joined to the work opportunities spread and an adequate infrastructure are measures that promote the reinsertion of the physical deficient people at the work market and at the productive life, as well as their reintegration at the social living, income increase and the life quality improvement in a general way ${ }^{[27]}$.
Though, those conditions devastates to the low acquisitive power at the studied group, in which the individual income were from a minimum salary and the familiar income between 2.65 salaries to sustain about 3.13 familiars. Sees that there is a vicious circle among the economy, education and deficiency, where the unfavorable interaction of those three factors put the physical deficient people between the poorest classes. In addition to the individual income, the familiar wage is also affected, because the dependence to another person, who is generally a close relative, generate two individuals who don't work and don't contribute to the familiar subsidy [28].

No doubly, the financial resources provided by the government to the physical deficient people in format of benefit or retirement are substantial to minimize impacts on incomes and to guarantee the social rights. However, it shall be considered that this population most vulnerability to the poverty and the increase of spending with health denotes to the lack of economical resources, as soon as a minimum wage is not enough to attend the survival necessities. This situation joined to the low educational level worsens the risk factors and social exclusion lived by deficient people in the society.

\section{Associations to the resilience}

The resilience level pointed by the physical deficient people was superior than the showed in a research with 136 physical deficient athlete aging from 18 years old or olders enrolled in sportive challenges, where the score was from $132.13^{[29]}$ and a study with 97 elderly users in a Basic Care Network in Northeast Brazil, where the resilience was from $134.14^{[30]}$

When stratify the sample per gender, was verified that the gender presented a significant relation to the general resilience, with the men presenting high averages. Corroborating to this assertive, a study developed with 69 physical deficient athlets ${ }^{[13]}$ showed that the men present high resilience levels. 
In this sense, Fernandes et al. ${ }^{[31]}$ justifies this situation in detriment to the physical and psychological different that there are between the genders, which cause more disturbances on women when due to changes that affect the physical body.

In an opposed interface, some studies describe that there aren't correlation between resilience and gender as reveal a researched that aimed to investigate the adaptation capacity and the sexual stem level in physical deficient athletes, in which, although $90.9 \%$ of the men and $87.5 \%$ of the women had obtained high resilience levels, it was not seen statistical evidences proving relation to those variables ${ }^{[13]}$.

Though the second correlation, it is verified that the marital status haven't showed influence on the physical deficient people resilience, and that, in despite of a non significant $p$, the single had higher scores at the factors "Action and Value Resolution", "Self-stem and capacity to adapt to situations" and general resilience when compared to the married ones.

This profile does not matches to a good part of the literature, because, nevertheless, being married is linked to a more independent life composition, with more availability to an instrumental support and emotional support, with a consequent improvement at the physical, psychological, social, environmental life quality and less depressive symptoms ${ }^{[32-33]}$. Researchers suggests that single individuals have 3 times more chances to point negatively in many life aspects, where at the men this value increase to 10 times and at the women to $4.5^{[34]}$.

Concerning to the religion, also wasn't observed statistical inferences on the resilience. To the opposite, the individuals inserted in spiritual practices showed a lower average in some factors at the Resilience Scale. This data is ratified by the Andrade et al. study ${ }^{[35]}$ evolving cancer survivals, where the most proportion of high resilience was on the individuals who haven't participated in religious practices. In despite of the data from this research don't refer relation to the religiosity adaptation capacity, field researchers consider that the religious engagement, understood as social support and coping strategies, provide comfort, well-being, a optimistic future vision, adjustments and internal resources to adversities overcoming, helping at the maintenance and to minimize the health aggravations and competing to the psychological resilience increasing [36].

Regarding the work, the statistic tests don't indicate association to the resilience, a condition that can be influenced by the expressive participants number who were unemployed, what would turn non probable the determination of this variable on the adaptive capacity in this specific sample. Although the lack of statistical inferences, resent studies have shown the job link to the resilient being construction. Authors explain that the work activities execution, in addition to possibility the income increase and the access to materials and consumer goods, constitute one of the main pieces to coping strategies elaboration and to minimize the harmful reaction risks in front of conflictive life events. The unemployed people have more tendency to develop stress symptoms and less resources to deal with the adversities $^{[37-38]}$.

The notorious position that has in the individual's life make the work induce the personal motivation and satisfaction. The fear and tension feeling that many live in the oppressive work practice, when in favorable contexts, possibility to the worker to overcome the obstacles, resign and promote resilience ${ }^{[39]}$. Data still prove that the participants' resilience hadn't suffered influence from the age, individual an familiar income. In this context, only the schooling had connection to the resilience factor. "Self-stem and capacity to adapt to situations". At the pertinent literature, there isn't a consensus about those correlations.

A study with elderly population indicates that there weren't statistical relation of the schooling and monthly economical income variables, emphasizing that the resilience is a peculiarity that don't 
distingue the socio economical classes ${ }^{[40]}$. The same was present in a study with diabetic patients, where the $p$-value obtained in association between the resilience and schooling was superior to $0.05^{[41]}$. In position, the research divulge that from the twenty-five questions from the resilience scale, five of them had statistical connection to the studied individual economical classes with myelomeningocele ${ }^{[13]}$

It is also added to the investigations that the association between resilience and age has showed as significant, expressing that the resilience capacity is acquired with the passing of years ${ }^{[5,35]}$. This characteristic is attributed to the experiences that the elderly people gather, in which many adversities and threatened satiations had already been overcome, believing that the acceptance and the adjustment to the limits develop and are solidified, because they belong to a spread lived story, contributing to an integrity and resilience sense ${ }^{[42-43]}$.

By this way, it is proved the divergence at the scientifically production as for the resilience and the individuals' socio demographic and economical profile. While for some authors the poverty can't be considered a determinant to low resilience levels, in this way not avoiding their development among the social groups ${ }^{[44-45]}$, others mention that a high instruction level and good financial conditions provide a higher knowledge capacity and information absorption concerned to threatening coping, personal adjustment and satisfaction with the life ${ }^{[12,32]}$.

Although studies have revealing the interface with individual attributes essentials to this process, the resilience exists in the human interactions with the environment, at the affections and at the social groups solidarity. Being resilient means to solidify personal and nontransferable strategies, what does not symbolizes vulnerability, much less the assurance that everyone will be able to overcome at the same way the adversities ${ }^{[46]}$.

\section{Conclusion}

Given the above, the found results points to the male gender predominance in the physical deficient people of the sample, in adult life, living in an stable union, with low schooling, who has a religion, are out of the work market and have as the main income resource the benefit/retirement provided by the government. From the socio demographic and economical profile studied, only the variables gender and schooling relate significantly to the participants' resilience, where the fact of being a man and having a satisfactory schooling level favorite to the adaptive capacity development contributing to high resilience averages.

However, it is noticeable at the same time, that concerning to other variables, the resilience is not dependent of some characteristics, taking to analyze this construct as a trait that can be build by any individual. What can be extracted from the portrait obtained in this study, is that in despite of the low income profile and poor education, the individuals showed high resilience scores with many contexts in which it is inserted becomes a hard task. The own acquired physical deficiency question includes a wide range of approaches that come from the body transformations till the impacts at the health and interaction to the environment, what increase the challenge in the investigation of these conceptions, specially when associated to the population social and economical conditions.

It is raised that this research conduction was pervaded for some limitations, presented at the literature scarcity regarding to the thematic at health and linked to the physical deficiency, a situation that restricted the works availability to the results discussion. It is added the reduced sample that disrupt the finding generalization to the community, as well as for the methodological design used, that, for its temporal cut characteristic, impossibility the causality inferences. Then, prospective studies with larger groups is seen as substantial to analyze the factors of the socio demographic effects and its influence 
on the resilience process evolution in the individual with acquired deficiency, must be encouraged and prioritized.

To the nursing, the results will serve as basement so that the nurse assistance may set aiming to instigate the construction of people with personal abilities through resilience fortification actions, by establishing news and more effective guidelines in health, aiming to provide an attendance focused on the true physical deficient necessities, not only oriented to the treatment and rehab of the deficiency condition.

At the public policies interface, it is expected that the study helps to spread the physical deficient people visibility, because makes the socio demographic characteristic study, in those including the coping capacity and adverse events, aiming to evaluate the implemented programs and redirect the attention to heal or at least minimize the evidenced gaps and give a feedback to the new strategies increment and intervention approach.

\section{References}

1. Cartilha do Censo (2010). Pessoas com Deficiência. Secretaria de Direitos Humanos da Presidência da República (SDH/ PR). Secretaria Nacional de Promoção dos Direitos da Pessoa com Deficiência (SNPD). Coordenação Geral do Sistema de Informações sobre a Pessoa com Deficiência. Brasília: SDHPR/ SNPD, 2012

2. Federação Brasileira de Bancos (FEBRABAN). População com deficiência no Brasil: fatos e percepções. Coleção Febraban de Inclusão Social, 2006.

3. Alves MLT, Duarte E. Relação entre a imagem corporal e deficiência física. Uma pesquisa bibliográfica. Revista Digital [Internet], 2010; 15(143). Available from: http://www. efdeportes.com/efd143/relacao-entre-a-imagem-corporal-edeficiencia-fisica.htm

4. Catusso RL, Campana ANNB, Tavares MCGC. F. A Resiliência e a imagem corporal de adolescentes e adultos com mielomeningocele. HU Revista [Internet], 2010; 36(1):3745. Available from: https://hurevista.ufjf.emnuvens.com.br/ hurevista/article/view/838

5. Garces SBB, Krug MR, Hansen D, Brunelli AV, Costa FTL, Rosa $C B$ et al. Avaliação da resiliência do cuidador de idosos com Alzheimer. Rio de Janeiro: Rev Bras Geriatr Gerontol [Internet],
2012; 15(2):335-52. DOI: http://dx.doi.org/10.1590/S180998232012000200016

6. Sordi AO, Manfro GG, Hauck S. O Conceito de Resiliência: diferentes olhares. Rev Bras Psicoter [Internet], 2011; 13(2):115-32. Available from: http://rbp.celg.org.br/detalhe_artigo.asp?id=61

7. Masiero CMT. A resiliência em pessoas com lesão medular que estão no mercado de trabalho. Uma abordagem psicossomática [Mestrado em Psicologia Clínica]. São Paulo: Pontifícia Universidade Católica de São Paulo; 2008.

8. Oliveira RA. Elementos psicoterapêuticos na reabilitação dos sujeitos com incapacidades físicas adquiridas. Análise Psicológica [Internet], 2000; 4(18):437-53. DOI: 10.14417/ap.391

9. Guerreiro $M$, Silva $A P$, Botelho MA, Leitão $A$, Castro-Caldas $A$, Garcia C. Adaptação à população portuguesa da tradução do Mini-Mental State Examination (MMSE). Revista Portuguesa de Neurologia. 1994; 1(9):9-10.

10. Pesce R, Assis SG, Avanci J, Malaquias J, Oliveira RVC. Adaptação transcultural, confiabilidade e validade da escala de resiliência. Cad Saúde Pública [Internet], 2005; 21(2):436-48. DOI: http:// dx.doi.org/10.1590/S0102-311X2005000200010

11. Seron BB, Arruda GA, Greguol M. Facilitadores e barreiras percebidas para a prática de atividade física por pessoas com deficiência motora. Rev Bras Ciênc Esporte [Internet], 2015; 37(3):214-21. DOI: http://dx.doi.org/10.1016/j.rbce.2013.09.003 0101-3289

12. Schoeller SD, Bitencourt RN, Leopardi MT, Pires DP, Zanini MTB. Mudanças na vida das pessoas com lesão medular adquirida. Rev Eletr Enferm [Internet], 2012; 14(1):95-103. Available from: http://www.fen.ufg.br/revista/v14/n1/v14n1a11.htm

13. Martins CP, Mendes AK, Cardoso FL. Capacidade de adaptação e estima sexual em atletas deficientes físicos. Rev Educ Fis UEM [Internet], 2011; 22(4):547-54. DOI: http://dx.doi.org/10.4025/ reveducfis.v22i4.10258

14. Ferreira M, Guerra MP. Adaptação à lesão vertebro-medular. Psicologia, Saúde \& Doenças [Internet], 2014; 15(2):380-95. Available from: http://www.scielo.mec.pt/scielo.php?script=sci_ arttext\&pid=\$1645-00862014000200005

15. França ISX, Coura AS, França EG, Basílio NNV, Souto RQ. Quality of life of adults with spinal cord injury: a study using the WHOQOL-bref. Rev Esc Enferm USP [Internet], 2011; 45(6):13647. DOI: http://dx.doi.org/10.1590/S0080-62342011000600013

16. Castro SS. Deficiência visual, auditiva e física: prevalência e fatores associados em estudo de base populacional. Cad Saúde Pública [Internet], 2008; 24(8):1773-82. DOI: http://dx.doi. org/10.1590/S0102-311X2008000800006

17. Duarte LS, Fernandes SF, Souza HAO. Traumas motociclísticos atendidos pelo corpo de bombeiros de Goiânia de Janeiro a Fevereiro de 2008. Cadernos de Estudos e Pesquisas [Internet], 2012; 16(36):41-6. Available from: http://www.revista.universo. edu.br/index.php?journal=1studospesquisa2\&page=article\&op =viewArticle\&path\%5B\%5D=996

18. Santana JCB, Dutra BS, Viana JÁ, Vieira LS, Cardoso CML. 
Vítimas de agressões por arma branca: o que retrata a demanda de um serviço de urgência. Cogitare Enferm [Internet], 2012; 17(1):78-84. DOI: http://dx.doi.org/10.5380/ce.v17i1.26378

19. Silva PYF, Dias JC, Santos WS, Kian GC, Rodrigues LB. Expressão da sexualidade em homens portadores de deficiência física adquirida. Revista Interfaces: Saúde, Humanas e Tecnologia [Internet], 2014; 2(6):1-4. Available from: http://interfaces. leaosampaio.edu.br/index.php/revista-interfaces/article/ view/156

20. Maia $A C B$, Ribeiro PRM. Desfazendo mitos para minimizar o preconceito sobre a sexualidade de pessoas com deficiências. Rev Bras Ed Esp [Internet], 2010; 16(2):169-76. DOI: http:// dx.doi.org/10.1590/S1413-65382010000200002

21. Lima FO, Silva NR. A educação de jovens e adultos e os desafios de uma proposta de educação inclusiva: perfil do aluno. Revista Temas em Educação [Internet], 2014; 23(1):144-51. Available from: http://periodicos.ufpb.br/index.php/rteo/article/ viewFile/18897/11445

22. Andrés A. Pessoas com deficiência nos censos populacionais e educação inclusiva. Consultora Legislativa da Área XV Educação, Cultura e Desporto. Câmara dos Deputados. Brasília - DF, 2014.

23. Silva EAPC, Silva PPC, Moura PV, Santos ARM, Dabbicco P, Azevedo AMP et al. Resiliência e saúde: uma análise da qualidade de vida em idosos. Conscientiae Saúde [Internet], 2012; 11(1):111-8. DOI: 10.5585/ConsSaude.v11n1.2709

24. Mesquita AC. The use of religious/spiritual coping among patients with cancer undergoing chemotherapy treatment. Rev Latino-Am Enfermagem [Internet], 2013; 21(2):07 telas. DOI: http://dx.doi.org/10.1590/S0104-11692013000200010

25. Ribeiro RPD, Lima MEA. O trabalho do deficiente como fator de desenvolvimento. Cadernos de Psicologia Social do Trabalho [Internet], 2010; 13(2):195-207. DOI: http://dx.doi.org/10.11606/ issn.1981-0490.v13i2p195-207

26. Amaral FLJS, Holanda CMA, Quirino MAB, Nascimento JPS, Neves RF, Ribeiro KSQS et al. Acessibilidade de pessoas com deficiência ou restrição permanente de mobilidade ao SUS. Ciênc Saúde Coletiva [Internet], 2012; 17(7):1833-40. DOI: http://dx.doi.org/10.1590/S1413-81232012000700022

27. Lopes MAL, Lima EDRP. Continuous use of intermittent bladder catheterization - can social support contribute? Rev Latino-Am Enfermagem [Internet], 2014; 22(3):461-6. DOI: http://dx.doi. org/10.1590/0104-1169.3268.2438

28. Santos S, Pequeno AAS, Galvão CRC, Pessoa ALS, Almeida ES, Pereira JC et al. As causas da deficiência física em municípios do nordeste brasileiro e estimativa de custos de serviços especializados. Ciênc Saúde Coletiva [Internet], 2014; 19(2):559-68. DOI: http://dx.doi.org/10.1590/141381232014192.00182013

29. Cardoso FL, Sacomori C. Resilience of athletes with physical disabilities: a cross-sectional study. Revista de Psicología del Deporte [Internet], 2014; 23(1):15-22. Available from: http:// www.redalyc.org/articulo.oa?id=235129571003
30. Ferreira $C L$, Santos $L M O$, Maia EMC. Resiliência em idosos atendidos na Rede de Atenção Básica de Saúde em município do nordeste brasileiro. Rev Esc Enferm USP [Internet], 2012; 46(2):328-34. DOI: http://dx.doi.org/10.1590/S008062342012000200009

31. Fernandes C, Beltrão BA, Chaves DNR, Leandro TA, Silva VM, Lopes MVO. Assesment of the resilience level of adolescents with leprosy. Rev Enferm UERJ [Internet], 2013; 21(4):496-501. Available from: http://www.e-publicacoes.uerj.br/index.php/ enfermagemuerj/article/view/10021

32. Resende MC, Neri AL. Atitudes de adultos com deficiência física frente ao idoso, à velhice pessoal e a pessoas com deficiência física. Estudos de Psicologia [Internet], 2005; 22(2):123-31. DOI: http://dx.doi.org/10.1590/S0103-166X2005000200002

33. Roncon J, Lima S, Pereira MG. Qualidade de Vida, Morbilidade Psicológica e Stress Familiar em Idosos Residentes na Comunidade. Psic: Teor Pesq [Internet], 2015; 31(1):87-96. DOI: http://dx.doi.org/10.1590/0102-37722015011637087096

34. Grigolatto T, Chagas MH, Trzesniak C, Crippa JAS, Hallak JEC, Santos JLF. A influência dos papéis sociais na qualidade de vida de portadores de esquizofrenia. Cad Ter Ocup UFSCar [Internet], 2014; 22(1):195-203. DOI: http://dx.doi. org/10.4322\%2Fcto.2014.021

35. Andrade FP, Muniz RM, Lange C, Schwartz E, Guanilo MEE. Perfil sociodemográfico e econômico dos sobreviventes ao câncer segundo o grau de resiliência. Texto Contexto Enferm [Internet], 2013; 22(2):476-84. Available from: http://www. scielo.br/pdf/tce/v22n2/v22n2a25.pdf

36. Simão MJP, Saldanha V. Resiliência e Psicologia Transpessoal: fortalecimento de valores, ações e espiritualidade. O Mundo da Saúde [Internet], 2012; 36(2):291-302. Available from: http:// www.saocamilo-sp.br/pdf/mundo_saude/93/art04.pdf

37. Valentim OS, Santos C, Pais-Ribeiro J. Vulnerabilidade ao stress em pessoas com alcoolismo. Revista Portuguesa de Enfermagem de Saúde Mental [Internet], 2014; (spe 1):76-81. Available from: http://www.scielo.mec.pt/scielo.php?script=sci_arttext\&pid $=$ S1647-21602014000100013

38. Victor JF, Ximenes LB, Almeida PC, Vasconcelos FF. Sociodemographic and clinical profile of elders who receive Care in a Family Health Unit. Acta Paul Enferm [Internet], 2009; 22(1):49-54. DOI: http://dx.doi.org/10.1590/S010321002009000100008

39. Ribeiro ACA, Mattos BM, Antonelli CS, Canêo LC, Goulart Júnior E. Resiliência no trabalho contemporâneo: promoção e/ou desgaste da saúde mental. Psicol Estud [Internet], 2011; 16(4):623-33. DOI: http://dx.doi.org/10.1590/S141373722011000400013

40. Fortes TFR, Portuguez MW, Argimon IIL. A resiliência em idosos e sua relação com variáveis sociodemográficas e funções cognitivas. Estudos de Psicologia [Internet], 2009; 26(4):455-63. DOI: http://dx.doi.org/10.1590/S0103-166X2009000400006

41. Tavares BC, Barreto FA, Lodetti ML, Silva DMGV, Lessmann JC. 
Resiliência de pessoas com Diabetes Mellitus. Texto Contexto Enferm [Internet], 2011; 20(4):751-7. DOI: http://dx.doi. org/10.1590/S0104-07072011000400014

42. Martins JA, Barsaglini RA. Aspectos da identidade na experiência da deficiência física: um olhar socioantropológico. Interface Comunicação Saúde Educação [Internet], 2010; 15(36):109-21. DOI: http://dx.doi.org/10.1590/S1414-32832010005000043

43. Silva Al, Alves VP. Envelhecimento: resiliência e espiritualidade. História de vida de idosos: superar as adversidades sem perder o senso de integridade. Diálogos Possíveis [Internet], 2007; 6(1):189-209. Available from: http://www.faculdadesocial.edu. br/dialogospossiveis/artigos/10/14.pdf

44. Yunes MAM. Psicologia positiva e resiliência: o foco no indivíduo e na família. Psicologia em Estudo [Internet], 2003; 8(Ed. Especial):75-84. DOI: http://dx.doi.org/10.1590/S141373722003000300010

45. Melillo A, Ojeda ENS (org.). Resiliência: descobrindo as próprias fortalezas. Porto Alegre: ARTMED; 2006.

46. Scriptori CC. Inclusão social, resiliência e docência: uma pista para construir fortalezas quando tudo parece o caos. Revista de Educação do Cogeime [Internet], 2007; 16(30):35-41. DOI: http://dx.doi.org/10.15599/0104-4834/cogeime.v16n30p35-41

Publish in International Archives of Medicine

International Archives of Medicine is an open access journal publishing articles encompassing all aspects of medical science and clinical practice. IAM is considered a megajournal with independent sections on all areas of medicine. IAM is a really international journal with authors and board members from all around the world. The journal is widely indexed and classified Q2 in category Medicine. 